використовувати індивідуальні бесіди та консультації, застосовувати методи програмованого навчання, диференціювати завдання для учнів за рівнем складності [5].

Висновки. Отже, узагальнюючи вищесказане, можна зробити висновок, що індивідуалізація трудового навчання відображає спрямованість освітнього процесу на особистість, на інтереси учня, на його нахили. У процесі реалізації підходу акцент робиться на персональні особливості діяльності, на характеристику якостей особистості, iii індивідуальні властивості, тобто беруться до уваги особливості кожного учня.

\title{
Література
}

1. Володько В. Н. Індивідуалізація та диференціація навчання: понятійнокатегорійний аналіз / В. Н. Володько // Педагогіка і психологія. - 1997. - № 1. - С. 9-18.

2. Костюк Г. С. Навчально-виховний процес і психічний розвиток особистості / Г. С. Костюк. - К. : Рад. школа, 1989. - 608 с.

3. Крутецкий В. А. Психология обучения и воспитания школьников / В. А. Крутецкий. - М. : Просвещение, 1976. - 303 с.

4. Онищук В. А. Дидактика современной школы : [пособ. для учит.] / В. А.Онищук. - К. : Рад. школа, 1987. - 351 с.

5. Поляков В. А. Политехнический принцип в трудовом обучении школьников / В. А. Поляков. - М. : Педагогика, 1977. - 215 с.

6. Терещук Г. В. Индивидуализация трудового обучения: дидактический аспект/ Г. В. Терещук. - М.: Ин-т ПСМ РАО, 1993. - 200 с.

Стаття надійшла до редакції 30.05.2012 р. аспірант,

\section{ФОРМУВАННЯ ФАХОВОЇ КОМПЕТЕНТНОСТІ ТЕХНІКІВ-МЕХАНІКІВ СІЛЬСЬКОГО ГОСПОДАРСТВА У ПРОЦЕСІ ВИВЧЕННЯ ФАХОВИХ ДИСЦИПЛІН}

\footnotetext{
Луговська Е. М. Формування фахової компетентності техніків-механіків сільського господарства у прочесі вивчення фахових дисциплін.

У статті розглянуто поняття «фахова дисиипліна», «фахова компетентність» технікамеханіка сільського господарства; уточнено фахові дисципліни спеціальності «Експлуатація та ремонт машин і обладнання агропромислового виробництвва та їх функиії.

Ключові слова: фахова дисиипліна, фахова компетентність, техніки-механіки сільського господарства.

Луговская Э.М. Формирование специальной компетентности техников-механиков сельского хазяйства в процессе изучения спещииальных дисииплин.

В статье рассматривается понятие «профессиональная дисииплина», «профессиональная компетентность» техника-механика сельского хозяйства; уточнены профессиональные дисциплины специильности «Эксплуатация и ремонт машин и оборудование агропромышленного производства» и их функиии.

Ключевые слова: профессиональная дисииплина, профессиональная компетентность, техники-механики сельского хозяйства.
} 
Lugovskaya E. The formation of the special competence of technicians, engineers hazyaystva agriculture in the study of special subjects.

In this article the term "professional discipline", "professional competence" mechanical engineering agriculture refined professional specialty discipline "Maintenance and repair of machinery and equipment agricultural production" and their functions.

Key words: professional discipline, professional competence, technology, agriculture mechanics.

Постановка проблеми. В умовах входження української системи вищої освіти до європейського освітнього простору та поглиблення інтеграції освіти, науки і виробництва, спостерігається стійка тенденція впровадження компетентнісного підходу до формування змісту та організації навчального процесу. Освітні результати і пріоритети за такого підходу зміщуються від досягнення конкретного рівня знань, умінь та навичок до володіння сукупністю компетенцій - універсальних (базових, ключових) і спеціальних (професійних, фахових) [3].

Необхідність формування фахової компетентності майбутніх техніківмеханіків агротехнічного коледжу зумовлена потребами суспільства в конкурентоспроможних кваліфікованих фахівцях, готових творчо застосовувати свої професійні знання, вміння та навички в різноманітних виробничих ситуаціях. Приєднання України до Болонського процесу та перехід вітчизняних ВНЗ на компетентісно-орієнтовний підхід в освіті окреслює нові напрями реформування освіти, а саме: якість та відповідність професійної підготовки майбутніх фахівців вимогам європейського та світового ринку праці.

Ефективність професійної діяльності сучасного техніка-механіка сільського господарства залежить від рівня сформованості його технічного та професійного мислення, готовності до професійної діяльності, а також від рівня його фахової компетентності, формування якої відбувається в процесі навчання у вищому аграрному навчальному закладі (ВАНЗ), зокрема у процесі вивчення фахових дисциплін.

Вивчення фахових дисциплін сприяє узагальненню та систематизуванню знань 3 фундаментальних та загальнотехнічних дисциплін, що покращує розуміння процесів і явищ, які відбуваються на виробництві.

Аналіз досліджень і публікацій. У теорію і методику навчання майбутніх фахівців аграрних навчальних закладів значний внесок зробили науковці Л. Аврамчук, І. Бендера, В. Гапоненко, О. Гуменюк, А. Дьомін, Н. Журавська, Т. Іщенко, В. Красильніков, П. Лузан, В. Манько, П. Олійник, П. Решетник, А. Рудь, В. Свистун, В. Скакун та інші. У їхніх працях розглядаються різні проблеми навчальної та виховної роботи у ВАНЗ.

Проблемам практичної підготовки фахівців-аграрників присвячено праці українських науковців О. Ващевської, Л. Вікторова, О. Данкєєва, В. Зайчука, I. Колоска, I. Паламара, М. Хоменка, безпосередньо інженерівмеханіків сільського господарства - В. Манько (теоретичні та методичні основи ступеневого навчання майбутніх інженерів-механіків сільського господарства), Л. Щербатюк (формування професіоналізму майбутніх інженерів-механіків у процесі фахової підготовки); техніків-механіків - 
В. Рябця (удосконалення практичної підготовки молодших спеціалістівмеханіків сільськогосподарського виробництва в агротехнічному коледжі), В. Лозовецької (теоретичні і методичні основи професійного навчання молодшого спеціаліста сільськогосподарського профілю). Науковці І. Бендера, Т. Пащенко досліджували проблеми організації самостійної роботи майбутніх фахівців з механізації сільського господарства у ВАНЗ у процесі вивчення спеціальних дисциплін.

Питанням професійної підготовки техніків-механіків у процесі вивчення загальнотехнічних дисциплін присвячено праці вітчизняних науковців О. Глазунової (методика навчання майбутніх фахівців аграрного профілю засобами комп'ютерної графіки), Н. Гловиної (формування дослідницьких умінь 3 дисципліни природничо-математичного циклу), С. Літвінчук (професійна підготовка техніків-механіків під час вивчення загальнотехнічних дисциплін), Л. Моторної (професійна спрямованість навчання природничо-наукових дисциплін у підготовці молодших спеціалістів технічного профілю) та ін.

Різні аспекти формування професійної компетентності техніківмеханіків під час вивчення фахових дисциплін розкрито в наукових роботах А. Посторонка (застосування методу проектів під час вивчення фахових дисциплін), І. Блозви (формування у студентів коледжу професійних умінь $\mathrm{i}$ навичок у процесі вивчення предмета «Сільськогосподарські машини»).

Водночас питання формування фахової компетентності техніківмеханіків сільського господарства під час засвоєння фахових дисциплін не можна назвати повністю вивченими.

Метою статті $\epsilon$ уточнення понять «фахова компетентність», «фахова дисципліна», а також обгрунтування впливу фахових дисциплін на формування фахової компетентності техніків-механіків сільського господарства.

Виклад основного матеріалу. У широкому розумінні фахова компетентність техніка-механіка сільського господарства - це властивість фахівця системно засвоювати фахові знання, використовувати набуті в навчанні уміння, навички і досвід під час розв'язання різного роду професійних завдань на підприємствах сільськогосподарського виробництва. Особливість фахової компетентності техніка-механіка полягає в наявності у фахівця поглиблених знань у сферах механізації, агрономії та основ сільськогосподарського виробництва.

Формування фахової компетентності майбутніх техніків-механіків відбувається в процесі вивчення фахових дисциплін, до викладання яких висуваються такі вимоги: дотримання цілісного підходу до вивчення професійної діяльності, використання міждисциплінарного аналізу в пошуках професійних рішень; побудови оптимальних моделей розв'язання майбутніх професійних ситуацій.

Для того щоб визначити вплив фахових дисциплін на формування фахової компетентності техніка-механіка, необхідно з'ясувати зміст понять «компетентність», «професійна компетентність», «фахова компетентність», «фахова дисципліна». 
У Проекті Закону України «Про вищу освіту» (нова редакція від 28.12.2011 р.) зазначено, що компетентність - це реалізаційна здатність особи, динамічна комбінація знань, розуміння, умінь, цінностей, інших особистих якостей, що описують результати навчання за освітньо-професійною, освітньо-науковою програмами і покладені в основу кваліфікації випускника [10].

У педагогічній теорії термін «компетентність» пояснюється як особистісна якість людини, яка формується 3 дитинства, закріплюється під час шкільного навчання і розвивається впродовж усього життя [2; 6; 7].

На нашу думку, «компетентність» - це здатність особистості володіти певною компетенцією, яка включає сукупність якостей фахівця (знань, умінь, навичок, досвіду, здібностей, особисте ставлення до відповідного виду діяльності) та здатність повністю реалізовувати свій потенціал у життєвій або професійній діяльності.

Під «професійною компетентністю» ми розуміємо здатність фахівця ефективно застосовувати сукупність набутих у навчанні у ВНЗ знань, умінь, навичок та досвіду, здатність швидко орієнтуватися в різноманітних професійних ситуаціях, здатність виконувати посадові обов'язки та функції, які входять до його професійних компетенцій.

Наше розуміння сутності поняття «професійна компетенція» узгоджується 3 думкою російського науковця А. Хуторського: це основні вимоги до професійних якостей, знань і вмінь фахівця, що визначаються відносно певної професійної діяльності і які необхідні для успішного виконання професійних обов'язків [13].

На основі вивчення науково-педагогічної літератури $[1 ; 4 ; 7]$ стосовно сутності та структури професійної компетентності фахівців, ми виокремили такі компоненти професійної компетентності техніків-механіків сільського господарства (рис.1).

«Фахова компетентність» - це здатність фахівця володіти знаннями, уміннями та навичками з професійних та фахових дисциплін; здатність творчо вирішувати професійні проблеми; уміння кваліфікованого виконання всіх видів професійної діяльності; володіння високим рівнем мотивації та саморозвитку. Здійснивши поглиблений аналіз змісту фахової компетентності техніка-механіка, ми виокремили такі його компоненти: фахові знання (загальнотехнічні, професійні, аграрні, екологічні, управлінські, технічні, технологічні), уміння, навички, самоаналіз, самоосвіта, ставлення до професії, професійна поведінка.

Компоненти фахової компетентності формуються через реалізацію освітньо-професійних програм і виражаються в освітньо-кваліфікаційній характеристиці фахівця.

Оскільки в сучасному освітньому середовищі досить часто використовуються терміни, пов'язані 3 фаховою дисципліною, нашим завданням є з'ясувати зміст поняття «фахова дисципліна». 

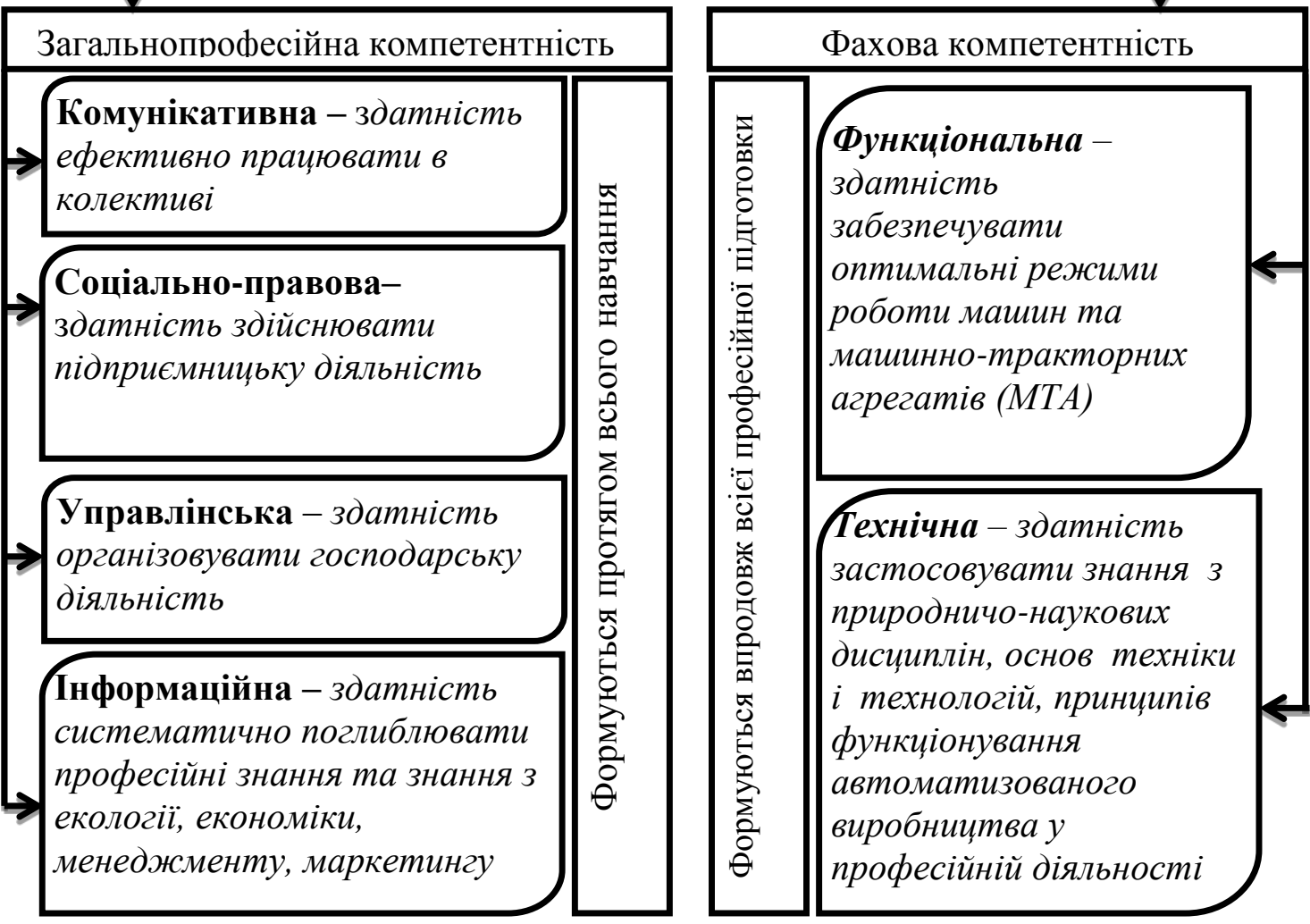

Рис.1. Структура професійної компетентності техніків-механіків сільського господарства

Термін «фахова дисципліна» спостерігаємо в таких документах, як Наказ Міністерства освіти і науки України № 847 від 24.12.2003 «Ліцензійні умови надання освітніх послуг у сфері вищої освіти» [5], у якому фахові дисципліни згадуються в пункті щодо складу науково-педагогічних працівників з науковими ступенями та вченими званнями, які забезпечують викладання аудиторних годин фахових дисциплін навчального плану спеціальності. Проте в цьому документі не пояснюється значення терміна «фахова дисципліна».

У «Сучасному тлумачному словнику» пояснюється термін «фахова дисципліна» як галузь наукових знань, яка викладається фахівцям конкретної спеціальності у вищих навчальних закладах [11]. Отже, фахова дисципліна - це один із засобів, форма подання змісту професійного навчання, головним об'єктом вивчення якого є цілісний процес розв'язання професійних завдань 3 використанням міждисциплінарних взаємозв'язків [12].

Ми окреслюємо такі функції фахових дисциплін:

- пояснювальна (фахові знання, зміст, організаційні форми й методи здійснення професійної діяльності);

- проектувальна (професійна адаптація);

- інтеграція фундаментальних, загальнотехнічних і фахових дисциплін (формуються знання з кожної навчальної дисципліни); 
- методологічна (використовуючи методологію та інструментарій фахової дисципліни, науковці розробляють власні методи і засоби дослідження процесів, які відбуваються в сільськогосподарському виробництві);

- прогнозувальна (можливість прогнозувати ефективність роботи того чи того МТА в конкретних виробничих ситуаціях, розвиток сільськогосподарського підприємства, його суб'єктів та об'єктів тощо);

- формувальна (формується професійне мислення та професійна поведінка).

Названі вище функції дозволяють реалізувати головну мету фахових дисциплін: засвоїти інфраструктуру та діяльність аграрного сектора економіки; засвоїти фахові знання, практичні вміння й навички роботи в сільськогосподарському виробництві; забезпечити суспільні і особисті потреби споживачів; опанувати вміння знаходити й реалізовувати ефективні рішення під час вибору оптимального складу та режиму роботи МТА, підвищенні продуктивності праці, зменшення енерговитрат та інших витрат на технологічну операцію, підвищення якості та кількості врожаю тощо.

Згідно 3 «Освітньо-професійною програмою підготовки молодшого спеціаліста напряму «Механізація сільського господарства», спеціальності 5.10010201 «Експлуатація та ремонт машин і обладнання агропромислового виробництва»»), у процесі професійної підготовки в агротехнічному коледжі, техніками-механіками передбачено вивчення таких фахових дисциплін [7]:

- основи агрономії;

- основи тваринництва;

- трактори й автомобілі;

- сільськогосподарські машини;

- механізація тваринництва;

- охорона праці;

- ремонт сільськогосподарської техніки;

- експлуатація машин і обладнання;

- правила дорожнього руху;

- основи керування автомобілем і безпека дорожнього руху;

- менеджмент сільськогосподарського виробництва;

- основи бухгалтерського обліку;

- основи агробізнесу і підприємства;

- механізація переробки та зберігання сільськогосподарської продукції;

- економіка сільського господарства;

- комп'ютеризація сільського господарства;

- електрообладнання та засоби автоматизації сільськогосподарської техніки;

- гідропривід сільськогосподарської техніки;

- паливно-мастильні та інші експлуатаційні матеріали.

У наведеному переліку фахових дисциплін відображається не тільки галузь знань, але й сфера майбутньої професійної діяльності техніка-механіка сільського господарства. Отже, під фаховими дисциплінами у підготовці майбутніх техніків-механіків освітньо-професійної програми «молодший спеціаліст» галузі «Механізація сільського господарства» ми розуміємо всі дисципліни, які входять до циклу професійної та практичної підготовки, та деякі природничо-наукові і загальнотехнічні дисципліни. Саме вони формують 
фахову компетентність, розширюють та поглиблюють професійну компетентність фахівця.

Висновки і перспективи подальших досліджень. У процесі вивчення фахових дисциплін (опанування теоретичного матеріалу, виконання практичних, лабораторних та розрахунково-графічних робіт) технікимеханіки оволодівають сукупністю фахових знань, умінь і навичок, що сприяють формуванню фахової компетентності, яка, у свою чергу, сприяє їхній ефективній професійній діяльності. Фахово компетентним технікоммеханіком сільського господарства ми вважаємо такого фахівця, який має глибокі теоретичні знання 3 вищезазначених фахових дисциплін, здатний самостійно і творчо розв'язувати виробничі проблеми сільськогосподарського виробництва, має здібності до саморозвитку й самоосвіти та прагне до підвищення рівня власної професійної компетентності.

\section{Література}

1. Воєвода А. Л. Формування фахової компетентності майбутніх учителів математики засобами розвитку пізнавальної активності: дис. ... канд. наук: 13.00.04 / Воєвода Аліна Леонідівна. - Вінниця, 2009. - 285 с.

2. Зимняя И. А. Ключевые компетенции - новая парадигма результата образования / И. А. Зимняя // Высшее образование сегодня. - 2003. - № 5. - С. 34-42.

3. Компетентнісний підхід у сучасній освіті: світовий досвід та українські перспективи: бібліотека з освітньої політики / [Бібік Н. М., Ващенко Л. С., Локшина О. І., Овчарук О. В. та ін.] ; за ред. О. В. Овчарук. - К.: К.І.С., 2004. - 112 с.

4. Костюк Д. А. Структура фахової компетентності майбутніх інженерівенергетиків сільськогосподарського виробництва [Електронний ресурс] / Д. А. Костюк // Нові технології навчання НУБіП України. - 2011. - Режим доступу: http://elibrary.nubip.edu.ua/9958/3/D.Kostiuk_St_NUBiP.doc.pdf

5. Ліцензійні умови надання освітніх послуг у сфері вищої освіти / Наказ Міністерства освіти і науки України № 847 від 24.12.2003 [Електронний ресурс ]. - Режим доступу до прогр.: http://www.mon.gov.ua/ license /nkz847/vo. doc. (12.11.09) - Загол. з екрану.

6. Маркова А. К. Психологический анализ профессиональной компетентности учителя / А. К. Маркова // Советская педагогика. - 1980. - № 8. - С. 82-89.

7. Овчарук О. В. Розвиток компетентісного підходу: стратегічні орієнтири міжнародної спільноти / О. В. Овчарук // Компетентісний підхід у сучасній освіті: світовий досвід та українські перспективи. - 2004. -111 с.

8. Освітньо-професійна програма підготовки молодших спеціалістів за спеціальністю 5.091901 «Механізація сільського господарства» / С. М. Бондар та ін. - К. : НАУ Центр з підготовки молод. спеціал., 1994. - 52 с.

9. Павлова Н. Формування у майбутніх учителів інформатики професійних компетентностей при вивченні фахових дисциплін / Н. Павлова // Вимірювальна та обчислювальна техніка в технологічних процесах. - 2011. - № 1. - С. 301-305.

10. Проект Закону України «Про вищу освіту»: нова редакція від 28.12. 2011 р. / Верховна Рада України. - Офіц. вид. - К. : Мін-во освіти, молоді і спорту України, 2011. 140 с. - (Бібліотека офіційних видань).

11. Сучасний тлумачний словник української мови: 100000 слів / В. В. Дубічинський. - Х. : ВД «Школа». - 2009. - 1008 с.

12. Чебышев Н.В. Что такое учебная дисциплина? / Н. Чебышев, В. Каган // Высшее образование в России. - 1997. - № 423. - С. 48-53.

13. Компетенции в образовании: опыт проектирования : [сб. науч. тр.] / под ред.

А. В. Хуторского. - М.: Научно-внедренческое предприятие «ИНЭК», 2007. - 327 с.

Стаття надійшла до редакції 24.05.2012 p. 